\title{
The Effectiveness of Jigsaw II Model in Improving Students' Understanding of Citizenship Education
}

\author{
Suroto \\ Universitas Lambung Mangkurat \\ Banjarmasin, Indonesia \\ suroto@unlam.ac.id
}

\begin{abstract}
Growing learners' motivation to study through the use of learning model is relevant to the challenges for professional educators. Jigsaw II cooperative learning model was the result of developing Jigsaw cooperative learning pioneered by Aronson. Learning model was a model whose one of the goals is to improve motivation and learning achievements in depth through understanding of lecture matter to study with to be made in more specifically. The effectiveness of jigsaw II cooperative learning model in college was already investigated and analyzed by using a qualitative method. The focus of this research was the effectiveness of Jigsaw II cooperative learning model in improving students' understanding on course materials. The results of the analysis showed that Jigsaw II cooperative learning model was one of the models which was more effective in improving students' understanding on course material of citizenship education in higher education.
\end{abstract}

Keywords-Effectiveness, Jigsaw II, Cooperative Learning Model, Understanding

\section{INTRODUCTION}

Education is an institution that serves as a place to improve the quality of human resources in a better direction and with quality. Through education, every learner is expected to get positive value in enriching scientific knowledge. Expectations through the world of education always soar in every nation including Indonesia. In relation to the learning process, it is better for every educator to use a learning model that is relevant to the material and learners.

Models are used to help clarify procedures, relationships as well as the overall state of what is designed. There are several uses of the learning models during the learning process which among others are: (1) clarify functional relationships among various components, elements or elements of a particular system; (2) provide procedures in the implementation of activities which can be identified appropriately; (3) With the model, the range of activities it covers can be controlled; (4) Models will make it easier for administrators to identify components, elements that constrain barriers if activities are ineffective and unproductive; (5) Correctly identify the ways to make changes, if the opinion of mismatch of what has been formulated exists; (6) Using the model, teachers can arrange student tasks into a unified form [1].
Learning model can be defined as a style or strategy undertaken by an educator in implementing the learning process. Certain procedure needs to be followed to achieve the desired goal. According to various studies, the use of learning models in a lecture can boost learners' understanding of learning materials and achievement. Learning models used by educators tend to vary, and one of the learning models used to improve student learning achievement is Jigsaw II cooperative learning model. Through the use of this learning model, learners are required to understand some lecture materials and then they will share knowledge with other students. Thus, there is a tendency that every student will learn from each other through the understanding they gain assisted by the educator as a facilitator. The uniqueness of Civic Education materials will be a challenge for educators in universities to prove whether through the use of Jigsaw II cooperative learning model can generate changes in understanding of students in college. Through this research, an analysis of the effectiveness of the Jigsaw II cooperative learning model in learning Citizenship Education in universities was presented.

\section{THE MATERIAL CHARACTERISTICS OF CITIZENSHIP EDUCATION IN HIGHER EDUCATION}

Citizenship Education is one of five traditions of Social Sciences Education on citizenship transmission, which has now developed into three aspects of Civic Education. They are academic, curricular, and socio-cultural aspects. Academically Citizenship Education can be defined as an area of study that focuses its study on all the psychological and socio-cultural dimensions of individual citizenship using political science and education as the basis of its study with its core discoveries enriched with other relevant disciplines and has useful implications for praxis instrumentation of education for every citizen in the context of the national education system [2].

Citizenship Education with a new paradigm is a field of scientific study on educational programs in educational institutions and is accepted as the main vehicle and the essence of democratic education in Indonesia It is implemented through: (1) civic intelligence, namely the intelligence and reasoning power of citizens in the spiritual, rational, emotional, and social dimensions; (2) civic reponsibility, namely awareness of their rights and obligations as responsible 
citizens; (3) civic participation, which is the ability of citizens to participate on the basis of their responsibility, both individually, social, as well as the future leader.

The Citizenship Education material should include three components, namely Civic Knowledge, Civic Skills, and Civic Disposition [3]. The first component, civic knowledge "relates to what content or value citizens should be aware of". This aspect concerns academic-scientific abilities developed from various theories or concepts of politics, law and morals. Thus, the subject of Civic Education is a field of multidisciplinary study. In more detail, Civic knowledge materials include knowledge of the rights and responsibilities of citizens, human rights, democratic principles and processes, governmental and non-governmental institutions, national identity, rule of law and free judiciary and impartiality, the constitution, as well as the values and norms in society.

Secondly, Civic Skills include intellectual skills and participatory skills in the life of the nation and the state. Examples of intellectual skills are skills in responding to various political issues, such as designing a dialogue with the DPRD. The example is participating skills that use their legal rights and obligations by immediately reporting to the police for a known crime.

Thirdly, the Civic Disposition, is actually the most substantive and essential dimension in the subject of Citizenship Education. The character dimension of Citizenship can be viewed as the "estuary" of the development of the previous two dimensions. By observing the vision, mission, and objectives of Civic Education subjects, as well as the characteristic of subjects characterized by emphasis on the dimensions of character, attitudes and other potential affective, it is not surprising that the use of Jigsaw II cooperative learning model becomes a right solution.

\section{THE JIGSAW II COOPERATIVE LEARNING MODEL}

Ref [4] states that a learning model is a broad and comprehensive approach and can be classified based on learning objectives, syntax (pattern sequence), and the nature of the learning environment. Jigsaw II cooperative learning model was developed by Slavin with little difference. By using Jigsaw II cooperative learning model in learning process, in general learners are grouped based on heterogeneous ability. Students are given new material or the previous material to be studied. Each member of the group is randomly assigned to become an expert on a particular aspect of the material. After reading and studying the material, "experts" from different groups come together to discuss the same topics from other groups until they become "experts" on the concepts they study. Students then go back to the original group to teach the topic they are mastering to their group members. At the end, students are given a test or assessment for all the topics provided.

There are some fundamental differences between Jigsaw II cooperative learning model that has been developed by Slavin and Jigsaw I. In Jigsaw I, initially students only learn a certain concept that will be their specialization while the other concepts are obtained through discussion with their partners in the same group. While in Jigsaw II cooperative learning model each student gets the opportunity to learn as a whole the concept that will be discussed in the learning process before they learn their specialty to become expert. It aims to obtain a comprehensive picture of learning materials or concepts that will be discussed.

The use of Jigsaw II cooperative learning model will enable each student to join in a group of experts. The expert will collect all the information, concepts and other skills related to the topic being studied. Students who are members of expert group are also required to teach the topic to members of the original group. In Jigsaw II cooperative learning model students are given the opportunity to collaborate with peers in the form of group discussion to solve a problem. This is because each group consisting of 4 to 5 students has heterogeneous academic ability, so that in one group there will be a highly skilled student, two or three medium-skilled students and a student with low ability.

There are 5 stages of the implementation of Jigsaw II cooperative learning model as follows [5]:

Stage 1: Reading. Students are grouped into basic/origin groups. Each member of the group is given a different sub subject/topic.

Stage 2: Expert group discussion. Students who get the same topic discuss in expert groups.

Stage 3: Group Report. The students return to the base group and will explain what they get in the expert group.

Stage 4: Test. Students are given tests covering all topics.

Stage 5: Group awards. The group score is calculated in the same way as the group scores on the STAD model.

The role of educator in Jigsaw II cooperative learning model is to direct the discussion, both in expert group and base /origin group. It becomes important because students study material rather than learn with lecture methods. In the Jigsaw II cooperative learning model type, students actively build their own knowledge. Students, of course, need the direction of educators to learn the material, especially the new materials.

While applying Jigsaw II cooperative learning model, students are grouped into basic group and then each group member is given different learning material to be studied. Students from the original group will be gathered in the expert group to discuss the materials assigned to each member of the group of experts who will then return to their respective base groups and take a turn for explaining the topics they get to members of their group. At the end, each student will be given a test of the concepts or learning materials that have been studied/discussed in the base group and expert group for all topics during the learning process. The score obtained from the test is considered as group score. The resulting score for their group is based on an increase in scores of each student. Improved scores are based on initial scores and final scores. 
The initial score is the score that the student has in the previous learning. The final score is the score that students get in the test given after the learning activities with Jigsaw II cooperative learning model. By comparing the two scores, teachers will get a progressive score of each student. These scoring criteria can be seen in Table 1.

TABLE I. MEASURES CALCULATIONS SCORE PROGRESS

\begin{tabular}{|l|l|}
\hline $\begin{array}{l}\text { Step 1 } \\
\text { Determining the base score }\end{array}$ & $\begin{array}{l}\text { Each student is given a score } \\
\text { based on past scores (pre-test) }\end{array}$ \\
\hline $\begin{array}{l}\text { Step 2 } \\
\text { Calculating the latest quiz score }\end{array}$ & $\begin{array}{l}\text { Students earn points for quizzes } \\
\text { related to current lessons }\end{array}$ \\
\hline $\begin{array}{l}\text { Step 3 } \\
\text { Calculating the highest score }\end{array}$ & $\begin{array}{l}\text { Students get the development } \\
\text { points determined by the basic } \\
\text { score and the highest quiz score }\end{array}$ \\
\hline
\end{tabular}

The individual progress score can be seen in Table 2 [5].

TABLE II. TABLE OF PROGRESS SCORING CRITERIA

\begin{tabular}{|c|l|c|}
\hline No & \multicolumn{1}{|c|}{ Test Scores } & Progress Score \\
\hline 1 & More than 10 points below initial score & 5 \\
\hline 2 & $\begin{array}{l}\text { Between 1 to 10 points below the } \\
\text { original score }\end{array}$ & 20 \\
\hline 3 & $\begin{array}{l}\text { Between 0 to 10 points above the initial } \\
\text { score }\end{array}$ & 30 \\
\hline 4 & $\begin{array}{l}\text { More than 10 points above the initial } \\
\text { score }\end{array}$ & \multicolumn{2}{|c|}{} \\
\hline
\end{tabular}

Group awards are awarded based on the progress scores of each group obtained by summing up the progress of each group's score and the score is divided by the number of teams taking the quiz. The average score of this group is also called the achievement score of each group. Based on the achievement scores, teacher gives a prize to each group that meets certain criteria. The criteria are shown in Table 3.

TABLE III. TABLE OF PROGRESS SCORING CRITERIA [5]

\begin{tabular}{|l|l|l|}
\hline No & \multicolumn{1}{|c|}{ Criteria } & \multicolumn{1}{c|}{ Title } \\
\hline 1 & $\mathrm{X}<15$ & Without title \\
\hline 2 & $15 \leqslant \mathrm{X}<25$ & Fair Group \\
\hline 3 & $20 \leqslant \mathrm{X}<25$ & Good Group \\
\hline 4 & $\mathrm{X} \geqslant 25$ & Very Good Group (super team) \\
\hline
\end{tabular}

For $X<15$, the groups will not get any title. This will encourage the groups who have not achieved significantly to learn more optimally and be more motivated to study the material well.

\section{THE EXCELLENCE OF JIGSAW II COOPERATIVE LEARNING MODEL}

Jigsaw Cooperative learning model learning is a cooperative learning model that focuses on group work in the form of small groups. Jigsaw II cooperative learning model assigns students studying in small groups consisting of 4-6 students who are heterogeneous and students work together to mutually create positive and responsible dependence independently. The steps of Jigsaw II cooperative learning model consist of: orientation, grouping, forming and coaching expert group, group discussion of experts in group, tests (assessment), and group recognition. One of the advantages of Jigsaw II cooperative learning model is to facilitate the work of educators in teaching. This is because there are already groups of experts assigned to explain the material to their peers. The distribution of material mastery can be achieved in a shorter time. This learning model can also be used to train students so they are willing to become more active in speaking and expressing their opinion. The weakness of this learning model is located on the main principle of this learning model, namely 'peer teaching'. This will be a constraint because the differences in perceptions in understanding the concepts discussed with other students can be understood differently by the other students. Learning will be less effective if students have no confidence in discussions or when delivering material to their friends in the original group. Students' understanding about the value, their personality and attention must be familiarized by educators which tend to take a long time in recognizing the types of students in the classroom. Preparation before implementing Jigsaw II cooperative learning model in the lecture process becomes very important for educators.

\section{THE EFFECTIVENESS OF JIGSAW II COOPERATIVE LEARNING MODEL IN IMPROVING STUDENT UNDERSTANDING OF CITIZENSHIP EDUCATION MATERIAL}

The cooperative learning model has advantages, especially in providing opportunities for students to deepen and understand the lecture materials independently. Through the process of learning independently, students are expected to have excessive desire to maximize their understanding themselves and to help their peers in understanding the material. The citizenship education material which tends to be narrative and needs insight in the form of knowledge of praxis and positive law regulation is considered difficult to be understood individually. Therefore, the use of learning model to help the mastery of the material in depth and thoroughly is needed as an effort to ease the burden of students in the lecture process. The results showed that the majority of students who are studying lecture materials, especially in civic education courses, tend to understand and master the lecture materials more easily. Students prefer Jigsaw II cooperative learning model because they are given an opportunity to explore important materials during lecture process and they also have obligation to convey the material to their peers. These findings are confirmed by [4] who states that a learning model is good in accordance with the following criteria:

The first criterion is valid. The aspect of validity is related to two things: whether the developed model is based on a strong theoretical rationale and whether there is internal consistency. Secondly, the practical aspect can only be met if 
the experts and practitioners state that what can be developed can be applied and the reality shows that what is developed can be applied. The third is effectiveness which relates to the judgement of experts and practitioners that the model is effective and relates to the desired results of the model.

Ref [4] provides a reinforcement that the Jigsaw II cooperative learning model used during the learning process, especially in the course of Citizenship Education tends to be effective considering the learning model is a learning model that can ease the burden of students in understanding the various materials. The use of this learning model during the lecture process can provide a significant impact on improving students' understanding of the lecture materials being studied.

\section{REFERENCES}

[1] M. Wena, Strategi Pembelajaran Inovatif Kontemporer: Suatu Tinjauan Konseptual Operasional, Jakarta: Bumi Aksara, 2011.

[2] U. S. Winataputra and D. Budimansyah, Civic Education Konteks Landasan, Bahan Ajar dan Kultur Kelas, Bandung: Sekolah Pascasarjana Program Studi Pendidikan Kewarganegaraan UPI, 2007.

[3] E. Solihatin, Strategi Pembelajaran PPKn, Jakarta: Bumi Aksara, 2012.

[4] Trianto, Mendesain Model Pembelajaran Inovatif-Progresif (Ed 4), Jakarta: Kencana Prenada Media Group, 2013.
[5] R.E. Slavin, Cooperative Learning 2ed, Needham Heights, Masaachuetts: Allyn and Bacon, 2005. 